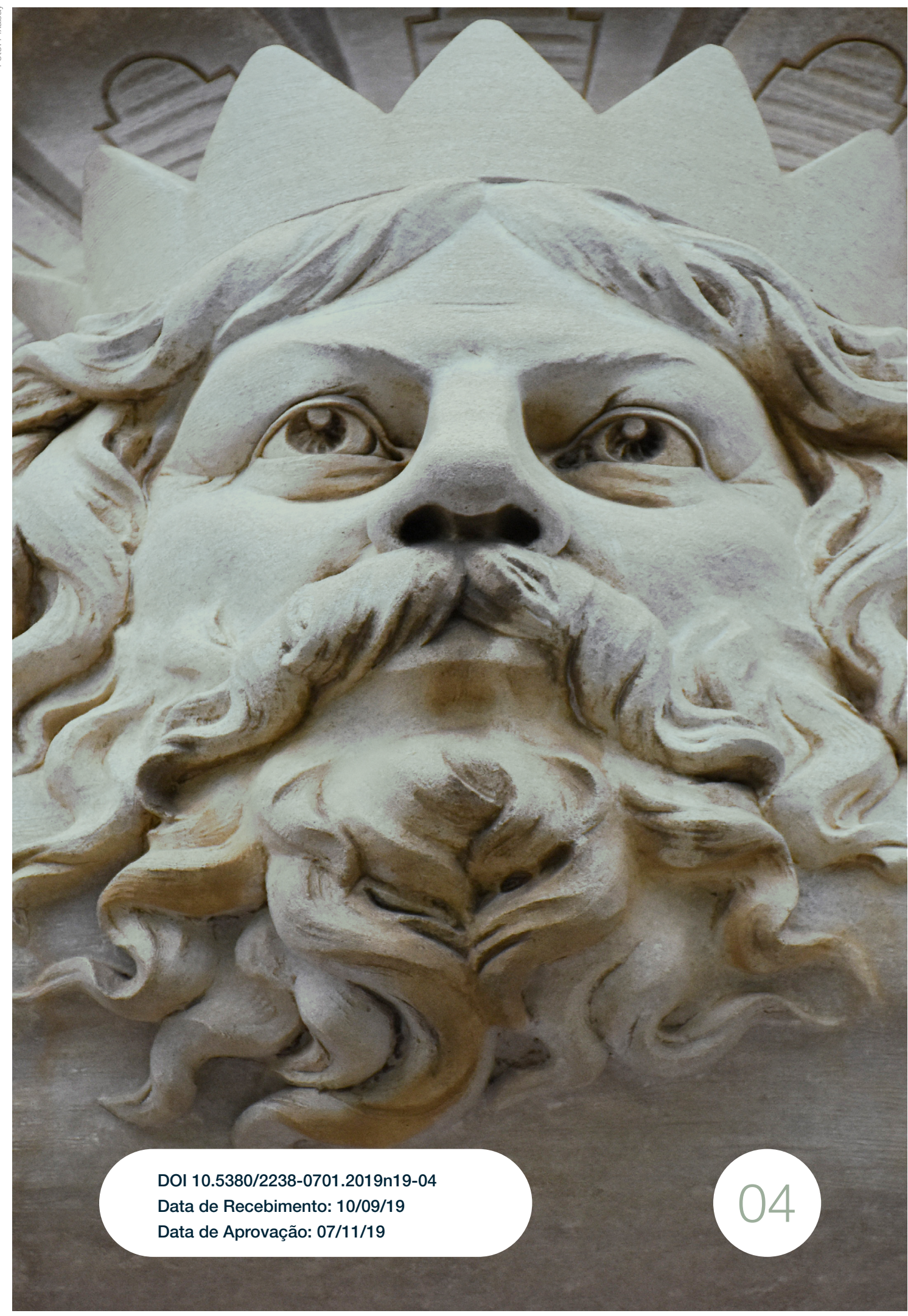


A construção mítica musical nas candidaturas de Lula à presidência 


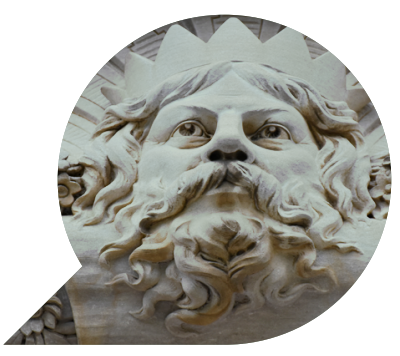

\title{
A construção mítica musical nas candidaturas de Lula à Presidência da República
}

\author{
The mythical musical construction in Lula's presidential \\ candidacies \\ La mítica construcción musical en las candidaturas \\ presidenciales de Lula
}

$\frac{\text { LUCIANA PANKE }^{1}}{\text { DEBORA MILLA }^{2}}$

Resumo: $\bigcirc$ artigo tem como objetivo a investigação acerca do conceito de mito de Lula aplicado nos vídeos de campanha eleitoral. O objetivo é identificar, à luz de Girardet (1987), quais elementos míticos foram atribuídos ao candidato. Luiz Inácio Lula da Silva foi candidato à presidência pelo Partido dos Trabalhadores (PT) nos anos de 1989, 1994, 1998, 2002, 2006, e em 2018 (ano este, de uma tentativa de candidatura impugnada, na qual o ex-presiden-

1 Professora Adjunta do Departamento de Comunicação Social da UFPR. Doutora em Ciências da Comunicação (ECA/USP) com pós-doutorado em Comunicação Política pela Universidad Autonoma Metropolitana (México). E-mail: panke@ufpr.br.

2 Mestranda em Comunicação pela Universidade Federal do Paraná. Bolsista CAPES. E-mail: deboramilla@ gmail.com.

3 Mestrando em Comunicação pela Universidade Federal do Paraná. Bolsista CAPES. E-mail: novo.eri@gmail. com. 
te se mantinha em cárcere). O corpus de análise é composto por um videoclipe de cada eleição. O resultado aponta que os jingles relacionam Lula ao mito, principalmente de herói, mas também o conecta aos outros três elementos que compõem a base para formação de um mito político: o da "idade de ouro", o da "conspiração" e o da "unidade".

Palavras-chave: Comunicação política; Lula; mito; campanhas eleitorais; jingles.

Abstract: The paper aims to investigate the concept of Lula's myth applied in election campaign videos. The objective is to identify, in the light of Girardet (1987), which mythical elements were attributed to the candidate. Luiz Inácio Lula da Silva was a presidency of the republic candidate for the Workers' Party (PT) in 1989, 1994, 1998, 2002, 2006, and in 2018 (this year, a contested candidacy attempt, in which the former president was arrested). The corpus of analysis consists of a video clip of each election. The result shows that the jingles relate Lula to the myth, mainly hero, but also connects him to the other three elements that form the basis for the formation of a political myth: the "golden age", the "conspiracy" and the "unity".

Keywords: Political communication; Lula; Myth; Election campaigns; Jingles.

Resumen: El artículo tiene como objetivo investigar el concepto del mito de Lula aplicado en videos de campañas electorales. El objetivo es identificar, a la luz de Girardet (1987), qué elementos míticos se atribuyeron al candidato. Luiz Inácio Lula da Silva fue candidato presidencial para el Partido de los Trabajadores (PT) en 1989, 1994, 1998, 2002, 2006 y en 2018 (este año, un intento de candidatura impugnada, en el que el ex presidente mantenido en la cárcel). El corpus de análisis consiste en un video clip de cada elección. El resultado muestra que los jingles relacionan a Lula con el mito, principalmente héroe, pero también lo conecta con los otros tres elementos que forman la base para la formación de un mito político: la "edad de oro", la "conspiración" y el "Unidad".

Palabras clave: Comunicación política; Lula; Mito; Campañas electorales; Jingles. 


\section{Introdução}

Qual relação entre imagem pública, mito e Lula? Há de se convir que o ex-presidente, como personalidade, transcende até mesmo sua vinculação partidária. Ele é, como personagem público, tanto amado quanto odiado, idolatrado como rechaçado. A expressão de sentidos resultante da sua formação como figura pública, foi norteadora para que esta investigação empírica se desenvolvesse. Dessa forma, o artigo pretende indicar, à luz de autores como Girardet (1987), as características fundamentais para a formação de um mito político, além de também se amparar em conceitos teóricos que discorram sobre o que caracteriza, tão somente, mito. Neste sentido, a partir do reconhecimento nas categorias elencadas pelo autor em sua referência a mitos políticos, a finalidade é identificar o que subjaz nesta transposição de significados dos quais se espera que o imaginário social absorva.

Destaca-se, porém, que o analisado na pesquisa não pretende dimensionar a construção identitária de Lula, nem a complexidade de sua imagem pública, mas sim relacionar em que medida o conceito de mito é evidenciado estrategicamente nos jingles de campanha eleitoral.

\section{Mito e mito político}

O conceito de mito no senso comum nos leva a pensar a respeito de uma noção falsa, de uma lenda, de uma mentira. Este mito é disseminado, por vezes, a partir de crenças que tem em sua incorporação a falta de reflexão a respeito da razão de sua existência. No contraponto, há também uma ideia de um ser admirado, idolatrado, ou que possua características distintas associadas a um caráter especial e único, pelo qual há um público específico a venerá-lo. É relacionado a fenômenos múltiplos, nos quais, entre variados contextos e ideias, fundamentam-se seus diversos significados (ROCHA, 2017).

Para discutir a respeito do conceito, é necessário recorrer a vários autores e até mesmo investigar como ele é disseminado em áreas diversas como filosofia, história, sociologia, e transcorrer épocas, da Grécia Antiga à contemporaneidade. Todavia, a complexidade de significações 
à volta do termo obstaculiza a integralidade de sua conceituação.

A palavra mythos, de origem grega, tem por definição a narrativa, a linguagem. Tem em sia narrativa de origem, tanto de deuses como dos homens, como a vida em comunidade (CHAUÍ, 1998, p.137). Na Grécia Antiga, as explicações mitológicas vinham definir e narrar simbolicamente acontecimentos históricos, de forma a justificar os fenômenos naturais. A utilização do mito como uma resposta aos acontecimentos consistia na sua relação com deuses, uma vez que não havia o amparo científico para explicá-los.

Essa narrativa pode vir a ser empregada no sentido inverso de logos, o qual relaciona-se ao racional, ao discurso, à realidade, ao pensamento, ou seja, mythos pode se contrapor a lógica. Para tanto, na ciência, na confirmação de "veracidade" a respeito de um determinado conhecimento, habitualmente se faz necessário converte-lo às explicações demonstrativas e racionais em contraponto àquelas que inicialmente justificavam-se somente em elementos míticos ou religiosos (CHAUÍ, 1998, p. 139).

Nesta percepção, Souza e Rocha (2009, p. 199) definem que "saindo do âmbito daquilo que não pode ser transformado em conceito, o discurso filosófico racionalizou e laicizou a narrativa mítica, procurando superá-la e deixando-a como coisa de um passado primitivo." Assim sendo, e no debate acerca de razão e mito, é que se tem respaldado na filosofia a exposição de ideias que unem ou opõem conceitos do que é gerado no senso comum e examinado no sentido crítico. Platão (2001), no livro "A República", discute em Alegoria da Caverna o estado de ignorância quanto ao mundo em que vivem os seres e, com base na razão, o que seria essencial para que se alcançasse o real mundo. Entre o mundo do sentido, aquele a ser experienciado (o qual causa uma falsa noção da realidade) e o mundo inteligível (o elaborado pelas ideias, o racional).

Alguns autores salientam que, mesmo se o mito pertencer a um plano diferente daquele verificado no campo científico, ele possui alto grau de relevância, além de uma "lógica própria", e se faz necessário sua existência e aprofundamento, visto que explicita, através de palavras, o entendimento e a acepção da realidade (SOUZA \& ROCHA, 2009).

A ficção presente em relatos míticos se torna realidade a partir do momento em que, para os que pertenciam à época, tais explicações 
faziam parte da própria significação de mundo no período vivido. Neste sentido, verifica-se a importância do mito para o estudo das comunidades antigas e até mesmo para a compreensão do pensamento humano (ELIADE, 2011).

Há ainda quem o defina, numa posição divergente, como "um sistema de comunicação, uma mensagem, um modo de significação, uma fala." (BARTHES 2006, p.199). Dito isto, para que ele possa existir, é necessária sua exposição em discurso. Visto que o discurso está para a política, assim como a política está para o que é público, o conceito de mito também pode vir a ser ampliado para um outro conceito, o de mito político. Quanto a um dos conceitos de mito político, Miguel discorre que "pode surgir no contexto de um discurso revolucionário tanto quanto de um discurso conservador ou retrógrado" (MIGUEL, 1998, p.3). Para o mito político a analogia que se faz é a sua combinação de meios de 'julgamentos factuais (racionais)' com 'juízos de valor (irracionais)' (MIGUEL, 1998, p.4). Ele se fundamenta como força capaz de conduzir a uma interpretação da realidade.

Girardet (1987) aponta que mito político é "uma fabulação, deformação ou interpretação objetivamente recusável do real”, ainda que também "exerça uma função explicativa" para a "explicação do presente" (GIRARDET, 1987, p.13). E que estes mitos políticos contemporâneos não se distanciam daqueles que eram considerados sagrados em comunidades antigas (Ibid, p.15). O autor elenca quatro teorizações/categorias como base para formação de um mito político. São elas: salvador, idade de ouro, conspiração e unidade.

O mito do salvador é o herói que aniquila e expulsa o mal, que em momentos de crise resolve problemas coletivos. De forma a superar as angústias sociais, o herói encarna o papel do qual a comunidade aguarda resolução. Há três fases para sua criação: uma de expectativa e sofrimento, que tem como objetivo formar o desejo por uma figura de herói; uma posterior, quando parece que as intenções do salvador estariam prestes a se realizar; e por fim, a lembrança do passado no qual a figura se modifica de acordo com grupos de interesses (GIRARDET, 1987).

Há, também, quatro modelos de representação distintos que caracterizam o salvador: um, o velho, que conquistou guerras do passado; um segundo, o jovem audacioso, que propõe aventura, uma ação imediata; um terceiro, o homem providencial, aquele que regido por princípios e 
instituições, alia-os a anseios presentes; e um quarto, o profeta, aquele que anuncia um novo tempo, um caminho para o futuro (GIRARDET, 1987).

Já na idade de ouro, a sua idealização encontra aporte nos discursos políticos do passado, é um apelo nostálgico de um tempo que parecia bom. É idealizado a partir de fragmentos da história e sendo imaginado como repleto, tem como consequência a fixação de um mito, visto que os tempos resgatados podem não ser fiéis, já que a memória não registra tudo de forma homogênea. Na busca de algo não vivido, um dado imaginário é criado e vestido em trajes de veracidade, sua condição reflete uma suposta realidade (GIRARDET, 1987).

O mito da unidade remonta à condição do próprio uso da palavra, a unidade de uma multidão. Por isso se relaciona a conceitos de nacionalismo, patriotismo, ordem nacional (GIRARDET,1987).

No que diz respeito ao da conspiração, a questão aborda o "outro" a ser combatido, no qual a imaginação é transferida para realidade. Portanto, quando as representações políticas disseminam propagandas ideológicas, estas retomam um primitivo atualizado segundo imagem constitutiva do inconsciente (GIRARDET, 1987).

\section{Mito e Lula}

Na afirmação de Lula como um líder carismático e em observação a sua trajetória transpassada por elementos simbólicos, o ex-presidente tem, na construção de sua imagem pública, uma narrativa que projeta referenciais de mito. A sua história é permeada por ascendências e descendências dignas de um romance literário. Do menino que mal tinha calçados imerso na pobreza do sertão de Pernambuco a sua eleição de dois mandatos consecutivos como presidente da República e, no presente, mantendo liderança em vários segmentos, ainda que esteja em cárcere ${ }^{4}$.

A análise de Bezerra (2011) considera que Lula teve na história de sua vida elementos para compor um personagem lendário. Sua origem e seus percalços semelhantes a um outro cidadão comum que incluem

4 Lula foi preso em 07/04/2018 após condenação em segunda instância no âmbito da operação Lava Jato, e libertado em 08/11/2019, após o Supremo Tribunal Federal ter considerado a prisão antes do trânsito em julgado inconstitucional. 
pobreza, dificuldade de formação, vontade e batalha pela sobrevivência até seu despontamento na vida pública, ascensão social/financeira e reconhecimento político são conteúdos simbólicos que produzem uma narrativa "mitologizada" (BEZERRA, 2011).

Panke (2014) estudou a trajetória política de Lula a partir dos discursos do ex- metalúrgico que chegou à Presidência da República. Em sua fase sindical, na década de 1970, contestava as relações entre capital e trabalho, defendendo a igualdade e um mundo sem dominantes e dominados. Com a criação do Partido dos Trabalhadores (PT), na década de 1980, os discursos traziam temas mais abrangentes, como a organização política e as decisões econômicas.

Já as campanhas eleitorais, de acordo com a autora, apresentaram modificações ao longo das disputas. Em 1989, por exemplo, Lula disputou o segundo turno representando a esquerda, seu discurso teve um viés influenciado pela carreira sindical em tom coloquial e crítico, inviabilizando o diálogo com as classes dominantes. Para chegar à campanha vitoriosa, o candidato precisou atravessar a fase de transição, abrandando o discurso, fazendo parcerias e adequando a estética durante a década de 1990. Em 2002, após a divulgação da "Carta aos Brasileiros", consagrou-se o "Lulinha paz e amor", que mostrou ser um candidato ponderado e estadista, mais preparado para assumir o cargo eletivo mais importante do país (PANKE, 2014, p. 184).

A espetacularização de seus atos públicos no palco midiático, ora apresentando-o como um "herói" ideal, ora como um "pai dos pobres", ora como um "inimigo" a ser combatido, expressa o quanto de carga é destinada à sua passagem política e o quanto de construção identitária Ihe é atribuída ao longo do tempo. Schwartzenberg (1978) enfatiza que o herói necessita de uma liderança carismática e que pode vir a ser representado ou como guerreiro, salvador ou profeta. E no exercício da política deve manter um prestígio que se apresente acima das massas, em terreno "sagrado", numa distância que lhe confira poder e mistério.

Para Lula é possível atribuir, dentre as teorizações ditas por Girardet, a categoria de herói. Visto que, tanto nos seus discursos, quanto na interpretação de sua trajetória, a imagem de "salvador" em fases de “apelo, poder, glória e martírio”, são percebidas (GIRARDET, 1987, p.66).

Os elementos discursivos também se configuram na "representação do que se faz de determinados fenômenos, pessoas ou ideias" e ain- 
da, "na contínua repetição e elaboração de uma imagem" (BEZERRA \& LIMA, 2009, p.2). Para tanto, é que se faz necessária a apreensão e o entendimento do que é exposto na mídia no que tange à contínua construção de sua imagem pública. Assim é que se tem o propósito de análise abaixo.

\section{O uso de jingles nas campanhas}

A música é um dos elementos de comunicação que mais repercute no emocional dos ouvintes. Panke (2012) considera que a música é um dos instrumentos universais do processo da comunicação, sendo capaz de despertar sensações comuns aos espectadores, como admiração e regozijo. Dessa forma, "os sentimentos, quando associados à música, potencializam-se, pois as melodias ultrapassam a comunicação sonora e facilmente geram associações diversas ao ouvinte" (PANKE, 2012, p. 09). Portanto, o uso da música é uma ferramenta importante para o contexto eleitoral devido a sua facilidade de memorização e seu poder de concisão.

A literatura apresenta alguns estudos sobre o uso de jingles em campanhas eleitorais. Lourenço (2009) o define como "uma pequena peça musical cuja função é a de facilitar e estimular a retenção da mensagem pelo ouvinte. O jingle é geralmente curto e sua melodia é ao mesmo tempo simples e de fácil compreensão (LOURENÇO, 2009, p. 205). Segundo o autor, sua origem remonta os anos 1930, ao surgir pela primeira vez como uma peça publicitária de uma emissora de rádio nos Estados Unidos. Quanto ao seu uso para fins políticos, Lourenço define o jingle tendo como objetivo "tanto conseguir apoio e votos a um político (partido, frente ou causa) quanto para criticar e diminuir apoio e votos a outro político (partido, frente ou causa) adversário" (LOURENÇO, 2009, p. 207).

Ferrari (2010) analisou o jingle da campanha de Lula em 2002 e constatou a importância do viés emocional como elemento chave no processo de decisão do voto, especialmente a partir do uso de dispositivos melodramáticos. No entanto, a autora pondera que o melodrama "não coloca as emoções dos eleitores como dispositivo de manipulação de suas decisões, mas sim como recurso interpretativo da mensagem 
política." (FERRARI, 2010, p. 83). Já o tempo de um jingle é variável conforme seu uso. Pode ser em uma inserção de rádio ou também editado com imagens para as peças de 30 segundos de televisão, em redes sociais digitais e no Horário Gratuito de Propaganda Eleitoral (HGPE).

Em uma campanha eleitoral, os jingles adquirem apelos mais emocionais que em campanhas políticas. Panke (2019) nos lembra que "nesta peça de campanha eleitoral está o posicionamento do candidato e é uma boa maneira de levar o nome do candidato aos lugares mais distantes". Na eleição, o jingle busca fixar na mente do eleitor a ideia chave do que se pretende comunicar.

\section{Análise dos jingles}

O corpus da pesquisa baseia-se na análise dos jingles de Luiz Inácio Lula da Silva nas eleições presidenciais de 1989, 1994, 1998, 2002, 2006 e 2018 veiculados durante o Horário Gratuito de Propaganda Eleitoral (HGPE) do candidato. Portanto, busca-se uma amostragem dos jingles editados em formato de videoclipe, considerando a interação entre imagem e som. Nesse sentido, são considerados principalmente a linguagem textual das letras e também o contexto em que ocorre cada eleição, tanto de Lula como político quanto das transformações tecnológicas que impactaram na edição do vídeo. Como referencial teórico, buscou-se aplicar o conceito de Girardet sobre o mito político.

O discurso a ser considerado é o eleitoral, um segmento do discurso político, materializado durante a campanha com objetivos específicos (PANKE, 2010). O discurso eleitoral tem um prazo de validade e é proferido em espaços públicos e temporais delimitados, como o próprio HGPE. O principal objetivo é persuadir o eleitor e vender uma ideia de futuro com elementos simbólicos para estimular o eleitor à ação, ou seja, o voto no candidato.

Durante o HGPE são explorados o caráter do candidato, promessas baseadas em demandas sociais, apelo à autoridade, realizações passadas, empatia e ênfase em discursos emotivos. Já o discurso político (CHARAUDEAU, 2006) vai além, não se restringindo ao ambiente eleitoral, mas perpassando toda a estrutura de poder, incluindo a atividade partidária, de movimentos sociais e a atividade pública em governos e no 
legislativo. Aqui nos interessa como o discurso de Lula durante o HGPE se relaciona com a ideia de mito. A análise é feita em ordem cronológica para medir como a imagem de Lula foi sendo moldada e transformada com o passar o tempo, assim será possível observar as diferenças no discurso e nas estratégias eleitorais construídas ao longo do período. Para a coleta, foram utilizados os vídeos disponíveis no Youtube.

A campanha de $1989^{5}$ foi marcada pelo jingle "Lula lá" de autoria do cantor e compositor Hilton Acioli, entoada por dezenas de artistas, como Chico Buarque, Lucélia Santos, Gal Costa, José Mayer, Betty Faria, Aracy Balabanian, Hugo Carvana, Joyce e Beth Carvalho. O material videoclipe produzido por Paulo Betti e Adair José foi a principal peça do HGPE da Frente Brasil Popular, formada por PT, PCdoB e PSB, para o segundo turno da campanha presidencial. Além dos artistas, aparecem vários militantes e apoiadores cantando em coro o tema também conhecido como "Sem medo de ser feliz". Ao fim, uma mensagem lembrava que todos os artistas participaram do musical voluntariamente por "acreditarem num Brasil melhor" com Lula presidente. Nesse período, em que Lula disputava a eleição presidencial pela primeira vez, o uso dos artistas passava a credibilidade que o político precisava para conquistar o eleitorado, especialmente aqueles que o consideravam inexperiente e com posições extremadas.

O jingle brincava com o nome do candidato e tinha o objetivo de fixar a ideia de que era preciso votar em Lula para ele ocupar a cadeira de presidente no Palácio do Planalto. O verso "sem medo de ser feliz" busca encorajar os eleitores a confiarem seu voto num candidato visto na época como um político menos moderado em relação ao oponente Fernando Collor de Mello, que venceu o pleito. Já o trecho "brilha uma estrela" faz referência ao símbolo do PT e projeta a imagem de Lula como uma figura com luz própria. Essa é também a metáfora que mais aproxima o candidato da ideia de mito em sua primeira campanha presidencial. A estrela remete ao céu, que tem uma ligação com o divino, com uma força maior. Na letra, mais do que no vídeo, é Lula que têm esse poder. No entanto, o jingle ficou marcado mais pela presença dos

5 Disponível em: <https://www.youtube.com/watch?v=kZF1f4eH3eA>Acesso em 15 de novembro de 2018. 6 Letra do jingle de 1989: Passa o tempo e tanta gente a trabalhar./ De repente essa clareza pra votar./ Sempre foi sincero de se confiar./ Sem medo de ser feliz./ Quero ver você chegar./ Lula lá, brilha uma estrela./ Lula lá, cresce a esperança./ Lula lá, o Brasil criança./ Na alegria de se abraçar./ Lula lá, com sinceridade./ Lula lá, com toda a certeza pra você./ Meu primeiro voto./ Pra fazer brilhar nossa estrela./ Lula lá, muita gente junta./ Lulálá, valeu a espera./ Lula lá, meu primeiro voto./ Pra fazer brilhar a nossa estrela.// 
artistas do que pelo candidato, que quase não aparece. Sem muitos recursos tecnológicos à época, o videoclipe é todo baseado na performance dos artistas cantando em conjunto, como num coral, numa espécie de arquibancada. Não há imagens externas cobrindo a música.

Em 19947 , o jingle ${ }^{8}$ reaparece na campanha de Lula para a presidência. Dessa vez, sem artistas e focado na imagem do candidato, que surge numa bandeira tremulando com retratos em que aparece sorrindo. No videoclipe, consta um varal com várias camisas de campanha onde é retirada uma com a mensagem "Lula Brasil" constando a bandeira do Brasil estilizada acompanhada da estrela vermelha do PT. A peça é passada com ferro enquanto vários pinceis surgem pintando o que se revela como um grande painel reproduzindo o mesmo logotipo do vestuário. Durante todo o videoclipe, a música serve como fundo para retratar a imagem de Lula e contrastar os símbolos nacionais com o do próprio partido. Uma mão formando o "L" de Lula surge ao fim fazendo referência ao nome do candidato.

Outra diferença no jingle de 1994 está na mudança da letra, que para além do refrão sofre algumas adaptações em relação a primeira versão. No entanto, a composição continua tentando construir uma imagem de político moderado. Agora, a estrela projeta sentimentos ao ser descrita como "serena, clareando os caminhos". Nesse sentido, o símbolo é usado para representar o personagem Lula. No jingle de 1994, o trecho "liberdade será o meu país" surge como destaque na tentativa de tornar o candidato mais moderado e capaz de respeitar as diferenças e as regras da democracia liberal. Já o verso "valeu a pena esperar" se conecta com a última campanha para sugerir um político que evoluiu e está mais preparado para conduzir o país. O mito Lula continua a ser projetado a partir da estrela, que passa a personificar em parte a figura do líder político. É Lula que vai fazer "brilhar a nossa estrela". Ou seja, a estrela por si só não tem brilho próprio e depende da iluminação de Lula, o que mais uma vez reforça o lado mítico do político.

A campanha de $1998^{9}$ abandonou o jingle 10 "Lula Lá" e investiu no

\footnotetext{
7 Disponível em: <https://www.youtube.com/watch?v=hGPfUrnQrcg> Acesso em 27 de novembro de 2018. 8 Letra do jingle de 1994: Lula lá./ Com sinceridade./ Lula lá./ Com toda a certeza.// Gentenaspraças, nasruas./ E assimvaivaler a pena./ Uma estrela serena./ Clareandocaminhos./ Se aprendevivendo a vida./ Ouvindo o que a vidadiz./ Prafazer com vontade./ De verdade um novo país./ De verdadeserá meu país.// Lula lá./ É a gente junto./ Lula lá./ Valeu a espera./ Lula lá./ Lula lá, Brasil, vem./ Pra fazer./ Brilharnosaestrela.//

9 Disponível em: <https://www.youtube.com/watch?v=2r-JJ_tfcLA> Acesso em 03 de dezembro de 2019. 10 Letra do jingle de 1998: Sómesmo o coraçãobrasileiro./Temrazão para seguiremfrente. / Meu país é genteprimeiro./ E a alegriapodevir num repente./ A vida é tãodesigual./ O bemtem que vencer o mal./ Coraçãobrasile-
} 
tema "Coração brasileiro" como mote. A principal diferença no videoclipe é a presença de cidadãos comuns, representando diferentes classes sociais e regiões do país. Portanto, marca uma diferença significativa em relação à primeira campanha eleitoral, centrada em artistas e personalidades. Agora, são pessoas comuns que ganham destaque. Lula aparece em alguns trechos conversando sorridente com esses eleitores. Aliás, o sorriso é a expressão que une todos os personagens, o que busca passar uma imagem positiva e de confiança, fugindo dos tons mais escuros e das gravações em estúdio registradas na campanha anterior. Dessa vez, o que prevalece é a imagem de um país produtivo construído pelos brasileiros, mas com desigualdades sociais a serem superadas. A edição ganha contornos cinematográficos, com imagens gravadas em vários cantos do país, com destaque para paisagens naturais e closes na expressão de cidadãos comuns.

A letra de "Coração brasileiro" apela para a emoção e exalta que só o "coração brasileiro tem razão para seguir em frente". O trecho que diz "o meu país é gente primeiro" faz referência ao fato de cuidar, de que as pessoas precisam de mais atenção por parte do presidente. A versão também destaca "a vida tão desigual" que assola o país. Portanto, o jingle se preocupa em retratar os problemas sociais e deixa de lado a centralidade na figura estelar de Lula. Por outro lado, o verso que defende que o "bem tem que vencer o mal" dá mais dramatização para a disputa e coloca Lula como um personagem virtuoso contra as vilanias que o país assistia com o presidente Fernando Henrique Cardoso, que buscava a reeleição. Assim, mais uma vez o mito de Lula é projetado, dessa vez centrado na ideia universal do bem contra o mal. Ou seja, é Lula quem vai combater as desigualdades para consolar o "coração brasileiro".

Em 2002 ${ }^{11}$, já na quarta disputa ao Planalto, Lula apostou em um novo jingle ${ }^{12}$, com o título de "Bota fé e diga Lula". O principal mote foi apostar na estrela vermelha símbolo do partido, servindo de fio condutor

iro./ Quemsabe é quemsente./ Lula soueu./ Lula é gente./ Coraçãobrasileiro./ Quemsabe é quemsente.// 11 Disponível em: <https://www.youtube.com/watch?v=mzl4H4-ebsw> Acesso em 12 de janeiro de 2019. 12 Letra do jingle de 2002: Não dá pra apagar o sol./ Não dá pra parar o tempo./ Não dá pra contar estrelas./ Que brilham no firmamento./ Não dá pra parar um rio./ Quando ele corre pro mar./ Não dá pra calar um Brasil./ Quando ele quer cantar.// Bote essa estrela no peito./ Não tenha medo ou pudor./ Agora eu quero você./ Te ver torcendo a favor.// A favor do que é direito./ Da decência que restou./ A favor de um povo pobre./ Mas nobre e trabalhador./É o desejo dessa gente./ Querer um Brasil mais decente./ Ter direito à esperança./ E uma vida diferente./ É só você querer./ É só você querer./ Que amanhã assim será./ Bote fé e diga Lula./ Bote fé e diga Lula./ Eu quero Lula.// 
de todo o vídeo. O ícone apareceu sendo bordado numa bandeira, que depois foi aberta por várias pessoas, na roda de uma bicicleta, na areia da praia e até dentro do bolso de uma calça jeans. Vários eleitores seguravam a estrela e passavam para outros como uma espécie de tocha olímpica, um símbolo de iluminação e celebração. A letra encorajava o público justamente para não ter "medo ou pudor" de colocar a estrela no peito. Na maior parte das cenas, o símbolo dividia o protagonismo com pessoas humildes fazendo trabalhos manuais, no campo e na cidade. Lula aparece apenas no final do filme abraçando uma estrela.

A letra do jingle transmitia uma mensagem de esperança, com uma força maior capaz de se impor diante do contexto político e social que o país atravessava. "Não dá pra apagar o sol, não dá pra parar o tempo, não dá pra contar estrelas que brilham no firmamento", o videoclipe une poesia e imagens da natureza. $O$ tom da melodia ganha ritmo que remete ao forró a partir do verso "não dá pra calar o Brasil quando ele quer cantar". Assim como na campanha de 1998, a letra destacava as desigualdades sociais e valorizava os trabalhadores mais humildes: "A favor de um povo pobre, mas nobre trabalhador. É o desejo dessa gente querer um país mais decente. Ter direito a esperança e a uma vida mais decente." O refrão dizia que a mudança dependia do eleitor: "É só você querer, que amanhã assim será. Bote fé e diga Lula, eu quero Lula".

O vídeo do jingle da campanha de 2002, ano em que Lula venceu a disputa, estava concentrado mais nas pessoas, nas paisagens, e menos na figura do candidato. A estrela vermelha serviu para representar a candidatura e o partido de Lula, sendo usada como símbolo para conectar-se com os eleitores de norte a sul do país. Nesse sentido, o mito Lula também foi construído a partir dos ícones que remetem ao seu partido e a sua ideologia política. Nesse jingle a imagem do candidato se funde com a da própria estrela. No final do vídeo, Lula abraça o símbolo como se fosse parte da mesma estrutura, uma extensão da sua identidade. O abraço também representa carinho e cuidado. Assim, a cena pode remeter à figura de um pai ao dar afeto e atenção aos seus filhos e, nesse sentido, figurar a do mito do herói.

Em 2006 ${ }^{13}$, a campanha de Lula transpôs em jingle ${ }^{14}$ imagens que

13 Disponivel em: <https://www.youtube.com/watch?v=1/QqA9Qr3yk> Acesso em 15 de fevereiro de 2019. 14 Letra do jingle de 2006: Do meu futuro eu não abro mão./ O que é certo eu não largo não./ Eu quero é mais do que me faz ter esperança./ O meu coração não cansa de me chamar para a razão./ Eu quero seguir em paz./ No rumo certo./ Não andar pra traz./ Eu quero é mais daquilo que me traz respeito./ E o orgulho do meu peito me dá força pra cantar./ Eu quero Lula de novo./ Com a força do povo./ Eu quero Lula novamente./ E o Brasil 
remetiam à ideia de alegria e orgulho pelo presidente que Lula foi. Nesse sentido, exaltavam pessoas felizes ora fazendo " $L$ " com as mãos, ora sorrindo, com adesivos, bandeiras, camisetas, entre outros. As pessoas pertenciam às mais diversas idades e etnias. Numa das falas do jingle há "do meu futuro eu não abro mão", assim como, "quero mais é o que me faz ter esperança”, demonstrando claramente o que Raoul conceitua um modelo de representação que traduz o "profeta", pertencendo também ao que o autor elenca como "herói". As imagens também demonstravam a unidade entre pessoas, onde aglutinadas cantavam juntas que "queriam Lula presidente". Essa expressão de povo remete ao que Girardet considera o mito da "unidade", que relaciona a condição de ação e postura que compõe uma unidade, seja um grupo, uma caracterização, ou, um manifesto. Uma ideia que traz consigo um fortalecimento, e como retratado, a "força do povo". Num contexto em que Lula já era presidente e tinha obras e resultados para mostrar, o objetivo era defender a continuidade dos projetos com versos como "Eu quero Lula de novo".

O jingle do vídeo ${ }^{15}$ de pré-campanha de Lula em $2018^{16}$, pode ser dividido em quatro fases distintas, as quais reforçam a tentativa de manutenção, ou mesmo, a afirmação de um candidato que "fez pelo Brasil" e "tem esperança num Brasil feliz de novo". As imagens da $1^{a}$ fase apresentam um sequencial que ilustram fechamento de empresas, diminuição de empregos (fazendo referência a uma carteira de trabalho dentro do bolso), subempregos, crises como a da gasolina, sol se pondo, aliado a cenas dos mais diversos tipos de pessoas com semblante desditoso, entre raças, idades e lugares diversos. Junto a este sequencial, a música produzida tem uma melodia melancólica. O jingle, essa mensagem publicitária em formato de música, tem o desígnio de proporcionar sensibilização, permite que o público tenha facilidade na apreensão de refrões e é utilizado como instrumento de marketing político.

Num momento de transição, tanto o sequencial de imagens como a música, convertem-se em uma outra narrativa. A trilha sofre uma modi-

seguindo em frente./ Eu quero Lula presidente.//

15 Disponível em: <https://www.youtube.com/watch?v=2wT25il6vMU\&t=9s > Acesso em 23 de fevereiro de 2019

16 Letra do jingle de 2018: Meu querido Brasil./O que fizeram com você?/ Tô sofrendo tanto por te ver assim./ E por todo o canto o choro é o lamento./ De um coração que grita em sofrimento./ Essa tristeza, meu povo, vai ter fim./ Olha lá, aquela estrela que tentaram apagar./ Não se apaga, não se rende./ É o brilho dos olhos da gente, olha ela lá./ Olha lá, uma ideia ninguém pode aprisionar./ O sonho cada vezmais livre./ Acesa a esperança vive, olha Lula lá./ Chama, chama que o povo quer./ Chama, chama que o homem dá jeito./ Chama que é bom, é Lula nos braços do povo./ Lula, livre./ É o Brasil feliz de novo.// 
ficação de ritmo e instrumentalização. Instrumentos que se assemelham ao gênero musical "forró" são utilizados e ouvem-se sons de triângulo, sanfona. Esse gênero musical faz parte da cultura popular brasileira e o intuito é o de gerar identidade, visto que o estilo musical intensifica o sentimento de pertencimento, de ser do "povo", e, segundo Francisco (2006, p.41), "símbolo dos retirantes" e, também, "produto a massa de eleitores".

Quanto às imagens da segunda fase, estas são relacionadas a momentos "felizes", sol nascendo, estudantes com mochilas, moradia, pessoas no campo, na praia, na cidade, em movimentos sociais, portos, indústria em funcionamento, caminhões na estrada, crianças jogando futebol, que intercalam com imagens da multidão de "fãs/eleitores" em comícios e/ou lugares nos quais o ex-presidente estava presente. Lula aparece sendo ovacionado e soerguido por estes, entre abraços, até mesmo sendo alçado em um quadro com sua fotografia na parede.

Em uma terceira fase do vídeo, uma locução na qual o próprio Lula narra (locução em off), ele manifesta que: "Os poderosos podem matar uma, duas ou três rosas, mas jamais conseguirão deter a chegada da primavera". Nesta passagem, vários rostos/pessoas de etnias e idades diferentes aparecem. Essa frase, uma variante ao dito por Che Guevara, é uma metáfora que vem a calhar justamente no momento em que se instaura a condição de Lula como preso, reforçando a ideia de uma analogia de que mesmo que uma força contrária política tente derrubá-lo, a ideia representada por ele, permanecerá.

Numa quarta fase, novas imagens de Lula no meio do povo, comícios, encontros, movimentos sociais, em meio a comunidades indígenas e religiosas. Há nesta mesma continuidade diversas imagens que fazem menção a "Lula Livre", além de um sequencial de fotos do ex-presidente em intensas demonstrações de afeto para com o povo, finalizando com o próprio Lula ilustrando com as mãos, um formato de coração. Esse é o jingle de Lula onde é possível identificar o maior uso de tecnologia e recursos de edição. Bem diferente da primeira campanha, praticamente sem cortes, o material apresenta imagens das mais diferentes fontes para resgatar a trajetória de Lula, incluindo drones mostrando planos abertos do alto. Já a infografia surge na legenda estilizada do discurso do candidato e na assinatura do logotipo de campanha. 


\section{Considerações finais}

Nos vídeos descritos, há as quatro categorizações, evidenciando traços que compõem um mito político, tal como proposto por Girardet. Um, na questão da idade de ouro, nas associações que são feitas a um período no qual foi presidente, correlacionando-as a uma data próspera, na qual o "emprego, o acesso a universidades, a moradia, crianças brincando, indústria funcionando, entre outros", eram fatores presentes, onde o recurso empregado é o de uma simulação de tempos áureos.

Também é possível fazer uma analogia quanto ao mito da conspiração, por representar o que seria de "mal" a ser combatido, tonificando o contrapoder a ser estabelecido, no qual, a esperança e felicidade tornam a "reinar". Há ainda o da unidade, que faz a correlação com a "força do povo".

O mito mais proeminente a ser observado é o de herói, dado que nos jingles, fases primordiais são identificadas. Uma, de 'expectativa e sofrimento" e outra de quando o "herói" está prestes a realizar as benfeitorias almejadas, o que no caso refere-se a Lula quando eleito. Da mesma forma, é construído seu "personagem" na figura que transita entre o "velho" e o "profeta", consequência de promover a imagem de Lula como aquele que "ganhou as guerras do passado", e ainda, "o que anuncia um novo tempo", "um sonho livre" onde "acesa a esperança vive". Assim sendo, a sua figura é concatenada a um "salvador" que irá resolver " o sofrimento do Brasil"e reparar " o choro e a tristeza do povo"; em consequência disso é enfatizado o homem Lula que é capaz de resolver problemas, pois os oponentes são os vilões da história, foram eles que a provocaram. Também lhe são atribuídas características acima de um homem comum, onde já não se configura somente sua forma humana. É a de que Lula transcendeu seus atributos terrenos e agora pertence a um campo da ideia. Assim sendo, somente ele é capaz de sanar as adversidades existentes, das quais os "eleitores" tanto almejam se libertar.

Pelo exposto, é compreensível averiguar que o conceito de mito por seu dimensionamento tão amplo e abrangente não consegue propor uma só visão a respeito, nem tampouco deve se ater a uma forma reducionista do termo. Dentre os que acreditam que ele se sobrepõe ao logos e aos que identificam a força e necessidade de sua presença, há um vale. Isso enquanto não perpassa dentre os autores que o qualificam 
com atributos outros (como o discurso) além do somente contraposto entre "mito" e "razão". Na sua condição alçada a de mito político, o conceito tende a uma nova abordagem de características. Esta reside em questões personalísticas, em discursos provenientes destas, o que também pode inclinar à absorção de narrativas de origem e aos processos advindos de mistificações.

Diante disso e, se adentrarmos na relação entre imagem, mito e Lula, o salientado por Girardet é conveniente com os elementos empregados nos jingles analisados. O intuito de prover uma imagem do ex-presidente associada a um "salvador" que liberta o povo da "tristeza", ou daquele que "trará a felicidade de volta" é consubstanciada, tanto pelo áudio quanto pelas imagens, que contrastam com a prostração imanente e a "esperança e alegria" ansiadas. Também, como já evidenciado acima, a "idade de ouro" manifesta-se no discurso, o qual designa, em áudio, um Brasil feliz com ele como presidente. Ademais, em correlação ao descrito pelo mito da conspiração, ele se fundamenta numa mescla associada ao herói, daquele que é perseguido, que se tenta derrotar e também no indício de que a oposição inferiu "tempos tenebrosos" ao povo e do qual o herói os desoprimirá. E ainda, como o já relatado, o mito da "unidade", elemento representativo bem realçado pelo "povo". Nesse processo de heroificação e, na disseminação de elementos simbólicos que acionam conceituações de mito correspondentes, a imagem pública de Lula vai sendo construída e alicerçada, corroborando a tentativa de que sejam absorvidos pelo público.

\section{REFERÊNCIAS}

BARTHES, Roland. Elementos de Semiologia. Tradução de IzidoroBlikstein, São Paulo: Cultrix, 2006. BEZERRA, Ada Kesea Guedes \&LIMA, Elizabeth Christina de Andrade. A Produção de Mitos na Política A Imagem Pública de Lula no Cenário Midiático. Portugal: Biblioteca Online de Ciências da Comunicação, s/d, 2009.

BEZERRA, Ada Kesea Guedes et al. O mito LULA: política, discursos e cenário midiático. 2011.

CHARAUDEAU, Patrick. Discurso político. São Paulo: Contexto, 2006.

ELIADE, Mircea. Mito e realidade. 6a edição. 2011.

FRANCISCO, Juliana Magalhães. Da cultura popular aos jingles políticos: uma análise cultural do forró. 2006. 
FERRARI, Maria Izabel Muniz. "Bota fé e diga Lula": o melodrama como viés interpretativo do jingle político. 2010.

GIRARDET, Raoul. Mitos e mitologias políticas. Tradução: Maria Lucia Machado. São Paulo: Companhia das Letras, 1987.

JULIEN, Alfredo. A psicologia histórica de Jean-Pierre Vernant. 2009.

LOURENÇO, Luiz Cláudio. Jingles Políticos: estratégia, cultura e memória nas eleições brasileiras. Aurora. Revista de Arte, Mídia e Política, n. 4, 2009.

MATOS, Lucas Pereira. A alegoria da caverna e seu mito hoje. Revista Pandora Brasil, n. 34, 2011.

MIGUEL, Luis Felipe. Em torno do conceito de mito político. Dados, v. 41, n. 3, 1998.

NUNES, Márcia Vidal. O rádio no horário eleitoral de 2002: a sedução sonora como estratégia de marketing. Paper apresentado no IV Encontro de Núcleos de Pesquisa do Intercom. 2004.

PANKE, Luciana. Política e entretenimento: cruzamento e/ou interferência na construção de sentidos. Animus. Revista Interamericana de Comunicação Midiática, v. 9, n. 18, 2010.

. Cantar para vencer: Reflexões sobre os jingles eleitorais. Comunicação Política e eleitoral, 2012.

_. Lula, do sindicalismo à reeleição: um caso de comunicação, política e discurso. Editora Unicentro, v. 2, 2014.

. Uma proposta de tipologia para os jingles. Rádio-Leituras, v. 6, n. 2, 2015.

. Criação publicitária para rádio. Curitiba: Intersaberes, 2019.

PLATÃO. A República. Lisboa: Fundação Colouste Gulbenkian, 2001.

ROCHA, Everardo. O que é mito. Brasiliense, 2017.

SCHWARTZENBERG, Roger-Gérard. O Estado espetáculo. Rio de Janeiro: Difel, 1978.

SOUZA, Ana Amália Torres; ROCHA, Zeferino Jesus Barbosa. No princípio era o Mythos: articulações entre Mito, Psicanálise e Linguagem. Estudos de Psicologia, Natal, v. 14, n. 3, p. 199-206, 2009.

VERNANT, Jean-Pierre. Mito e Religião na Grécia antiga. Tradução: Joana Angelica D’Avila Melo. WMF, São Paulo, 2009.

Data do recebimento: 10 setembro 2019

Data da aprovação: 07 novembro 2019 


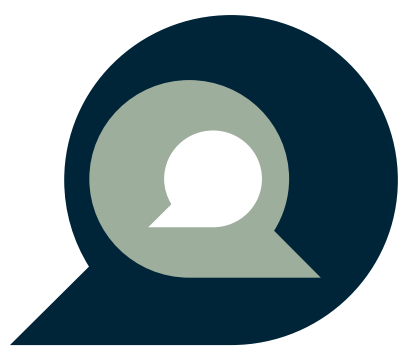

